\title{
European macroeconomic imbalances at a sectorial level: Evidence from German and Spanish food industry
}

\author{
Juan Aznar (iD), Josep Maria Sayeras (iD), Ricard Lascorz (iD), Borja Raventós (iD) \\ ESADE Busines and Law School, Ramon Llull University (Spain) \\ juanpedro.aznar@esade.edu,josepm.sayeras@esade.edu,ricard.lascor_@alumni.esade.edu,borja.raventos2@alumni.esade.edu
}

Received June, 2017

Accepted January, 2018

\begin{abstract}
Purpose: This research has analyzed the structural differences observed comparing medium size Spanish and German firms in the food industry, specifically biscuit production. A second objective has been to analyze if the different macroeconomic conditions in Spain and Germany have affected the performance of firms.
\end{abstract}

Design/methodology: Using financial information from AMADEUS data base, a sample of firms (135 observations) in the food industry from Spain and Germany have been analyzed, considering the changes observed in the periods 2007-2009, 2010-2012 and 2013-2015. Productivity, real investment, cost per employee, profitability and interests paid by the firms are among the variables considered. The different hypotheses proposed have been tested using non-parametric test, mainly, Mann-Whitney test and Rho Spearman coefficient.

Findings: Medium size German firms are bigger, using number of employees, than Spanish firms and show a higher profitability (using ROE) whatever the period consider. The evidence suggests that after a certain threshold size the correlation between size and productivity is negative. An interesting result is the negative correlation between interest rate and labour productivity; financial conditions can have a clear effect on firm's performance. At this sector level there is no evidence of the process of internal devaluation, probably because the growth observed either by increase in real investment or sales have been accompanied by the need to hire skilled labour.

Research limitations/implications: The main limitation is that this research has only focused on particular economic activity, biscuit producers, to include others firms in the food industry must be considered in future research.

Practical implications: Size is a strategic decision that managers must face, to understand how labour productivity and financial performance is affected by size will help to take the optimum decision. The performance of the firm is also partially affected by the interest rate that the firm faces, the negative correlation found between interest rate and labour productivity is important in informing right decisions about increasing firm's debt level.

Social implications: Europe is rethinking industrial policy in the aftermath of the financial crisis (20082009) and in a global context with an increasing number of industrial activities locating in low labour costs destinations. Understanding the structural differences that industries across the European countries show is a key factor in deciding an efficient industrial policy. 
Originality/value: The last decade has accentuated the macroeconomic differences, in terms of long term interest rates or levels of unemployment between the core of Europe, Germany, and the periphery, including countries like Spain. This research is one the first ones in analyzing how these differences are affecting financial performance and structural differences in a particular industry, that is one of the most important exporters of the European Union.

Keywords: Food industry, Labour productivity, Firm's size, Financial conditions

Jel Codes: L66, L25, D24

\section{Introduction}

The 2008 financial crisis has usually been compared with the Great Depression, based on some similarities. To point out some of them, the rapid growth of debt to GDP previous to the recession period, the important overinvestment in some sectors, as housing sector in Spain or Ireland (2001-2008), and the fragility of the banking system. However, the Euro area represents a singular situation, with 19 countries adopting a single currency and applying a unique monetary policy. The political decision of creating a currency union was taken although the different economies in the Euro area show many important disparities and are far from being considered an economic region with high levels of productions factor mobility, the important differences in unemployment rates would not exist in a situation of high labour mobility, and clear important differences in their economic structures.

Some authors argue that for the countries that experienced losses of competitiveness, caused by higher rates of inflation than the countries at the core of the Euro area (Germany, Netherlands, France or Belgium) since the adoption of the Euro to the start of the financial crisis (Spain, Italy, Portugal or Greece); the only solution to recover competitiveness is the internal devaluation process (Armingeon \& Baccaro, 2012; Stockhammer \& Sotiropoulos, 2014). It can be defined as a real salaries reduction compared with the evolution of the core European countries, mainly Germany. This effort to reduce production costs allows prices reductions by the firms located in these countries and allow to improve the competitiveness lost in the past, measured through the real exchange rate, boosting their exports and finally increasing profitability. The internal devaluation is not the only way to recover competitiveness; there are growing concerns on the importance of production activities off shoring to countries with lower labour cost. Although China gets the credit of becoming the World factory, this process has also involved the investment in Eastern European countries by Western European (Marin, 2006).

Macroeconomic conditions have been different for the Spanish and the German economy. The Euro area have suffered a double recession, a first one in 2008-2009 as a consequence of the financial instability that spread from United States to the rest of the World, and a second one that was consequence of the lack of confidence on some European governments' capacity to pay back their almost exponentially growing levels of public debt. Greece with a public debt of $179.7 \%$ of the GDP in 2014 but also Spain with public debt rocketing from 35.9\% of the GDP in 2008 to $100.4 \%$ in 2014, Eurostat (2017), these are two clear examples of public finance deterioration. These data contrast with German evolution that in the same period showed a public debt as a percentage of GDP from $65.1 \%$ to $74.9 \%$. The differences observed in the values and evolution of public debt and the lack of confidence have affected the interest rate at which governments have financed their debts, but also the interest rate that firms from these countries have to pay when deciding to increase their stocks of capital, (Becker \& Ivashina, 2014). There is empirical evidence of non-financial corporation in some south European countries facing higher nominal interest rate highly correlated with the risk premium observed in the public bonds market (Pianeselli \& Zaghini, 2014). These differences in financing cost can have an effect on real investment and the growth of labour productivity. A second macroeconomic clear difference is the labour market situation and how it deteriorated in the financial crisis period. Germany unemployment rate was 7.4\% in 2008 and the value for the last year available, 2016, is 4.1\%; an opposite evolution can be seen in Spain where the rate of unemployment was $11.3 \%$ in 2008 and achieved a maximum of $26.1 \%$ in 2013 , improving in the last years and with a current level of $19.6 \%$ in 2016. Although, evolution of wages would depend on many other factors, from the labour market regulation to the differences in the role played by trade unions, the higher levels 
of unemployment in Spain have pressured for lower salaries contributing to the internal devaluation process. Some of the differences observed in macroeconomic indicators that can impact on firms' performance have been summarized in Table 1.

\begin{tabular}{|c|c|c|c|c|c|c|c|}
\hline & 2009 & 2010 & 2011 & 2012 & 2013 & 2014 & 2015 \\
\hline SpanishPublicDebt (\% GDP) & 52.7 & 60.1 & 69.5 & 85.7 & 95.4 & 100.4 & 99.8 \\
\hline German PublicDebt (\% GDP) & 72.6 & 81.0 & 78.7 & 79.9 & 77.5 & 74.9 & 71.2 \\
\hline Rate of unemployment (Spain) & 17.9 & 19.9 & 21.4 & 24.8 & 26.1 & 24.5 & 22.1 \\
\hline Rate of unemployment (Germany) & 7.6 & 7.0 & 5.8 & 5.4 & 5.2 & 5.0 & 4.6 \\
\hline Long term interest rate( Spain) & 3.98 & 4.25 & 5.44 & 5.85 & 4.56 & 2.72 & 1.73 \\
\hline Long term interest rate ( Germany) & 3.22 & 2.74 & 2.61 & 1.50 & 1.57 & 1.16 & 0.50 \\
\hline Consumer Price Index (Spain) & -0.2 & 2.0 & 3.0 & 2.4 & 1.5 & -0.2 & -0.6 \\
\hline Consumer Price Index (Germany) & 0.2 & 1.1 & 2.5 & 2.1 & 1.6 & 0.8 & 0.1 \\
\hline External current account ( $\%$ GDP) Spain & -4.3 & -3.9 & -3.2 & -0.2 & 1.5 & 1.1 & 1.4 \\
\hline External current account (\% GDP) Germany & 5.7 & 5.6 & 6.1 & 7.0 & 6.7 & 7.3 & 8.3 \\
\hline
\end{tabular}

Table 1. Macroeconomic indicators, Spain and Germany. Source: Own elaboration based on Eurostat data

The objective of this paper is to analyze if the mentioned macroeconomic differences between European countries, using the cases of Germany and Spain, have affected the evolution of manufacturing firms in a particular sector. Variables analyzed include differences in profitability, productivity, cost per employee and investment growth, as sensitive variables to different structural and macroeconomic conditions. The sector chosen has been the Food industry. According to the European Union Commission (2016) it is the biggest manufacturing industry in terms of jobs and value added, and has doubled its exports in the last 10 years. In 2012 the exports by EU firms on the food sector represented 12.1\% of the market share, 4 percentage points above the US market share. If we consider the subsector of biscuits production the importance of the German and Spanish firms considering that they own the $36.9 \%$ and $25.5 \%$ of the private labels, with higher values than the ones observed in France (21.4\%), United Kingdom (21.3\%) or Italy (16.7\%) (European Commission, 2016).

The structure of the paper is as follows. Section 2 summarizes the main academic literature, section 3 describes the data used and the methodology applied and finally, section 4 discusses the results and future lines of research.

\section{Literature review}

Although European countries belonging to the European Union share a single market with production factors mobility freedom, including capital but also labour, structural conditions remain significantly different among countries. One important variable is firms' size, measured either by total value of assets or number of employees. Several studies have tried to determine if there is an empirical positive correlation between size and profitability (Doğan, 2013) or size and total factor productivity (Bartelsman, Haltiwanger \& Scarpetta, 2013). Spanish firms have in average a lower size than German firms and the share of small firms is higher in Spain. According to the last available date at Eurostat database (2017) in 2014 a 29.62\% of German firms had between 1 and 4 employees, this rate was a 34.77\% for Spain. On the other hand, considering firms with more than 10 employees the data were a $12.36 \%$ for German firms and only a 3.67\% for Spanish active firms.

The size of the firm is clearly linked to the development of financial markets, and the capacity for small firms to get access to the financial resources needed to invest and growth. European firms in general are more dependent to bank credit than accessing to stock markets. Country factors are important in explaining different access to bank lending and firms' size, firms' age and rate of growth can be explanatory variables. (Bergthaler, Kang, Liu \& Monaghan, 2015; Canton, Grilo, Monteagudo \& van der Zwan, 2013; Jõeveer, 2013). The financial recession in 2008 and the Euro area public debt crisis in 2012 have led to a process of credit crunch (Dimelis, Giotopoulos \& Louri, 2013), a situation of credit contraction that has affected the firms' capacity not only to finance new investment in non-current assets, even made more difficult to finance their daily operations. These difficulties in accessing to bank lending and higher interest rate can negatively affect the level of real investment, with an impact on labour productivity and innovation, reducing the competitiveness of the firm. 
An important expected difference that would be interesting to analyze at a sector level refers to the internal devaluation process that south European countries have lived as a way to recover past losses of competitiveness. De Grauwe (2013) has analyzed the problems related to the Eurozone design and two important issues related to the internal devaluation process. The first one, is that internal devaluation has implied important costs in terms of more unemployment and low economic growth for the south European countries that have applied it; the second one is that this process has not been as successful as it can be if the core European countries have decided to increase their demand, by a more expansionary fiscal policy or an increase in their real wages. In fact, after the German reunification Germany applied an internal devaluation that helped to boost its exports and from 2009 to now have remained stable with not significant increases in salaries. Regan (2015) argues that the existence of important differences between countries following an export-led model, like Germany, and others like Spain, Portugal or Greece following a demand-led model. To understand the differences in these two models are a prerequisite to develop and appropriate economic policy response (Storm \& Naastepad, 2015). More data analysis related to particular sectors can help to understand how these macroeconomic changes affect firms in a particular sector.

The interaction between financial crisis and the real economy has been a key topic in economics and business literature (Bernanke, 1983). The credit contraction consequence of a financial crisis can lead to a long period of recession as it affects the financing cost of households and firms, or even governments, reducing aggregate demand and leading to an output contraction. From a microeconomic perspective small firms' productivity benefits from an improvement in credit condition access (Krishnan, Nandy \& Puri, 2014). The empirical evidence for Europe suggests that the conditions in each country have an important role in the observed differences in firms' interest rates and the barriers found in receiving loans from commercial banks (Ferrando et al., 2015). Higher levels of indebtedness affect negatively new investment and there is a positive correlation between sales growth and higher levels of investment. The contraction of credit known as credit crunch has affected the small and medium size firms' capacity to access to financial markets, specially banking credit, however individual firm's conditions also play an important role in how difficult is to access to bank loans (Holton, Lawless \& McCann, 2013).

This paper focuses on analyzing the existence of different conditions for medium size firms comparing Spain and Germany, with clear differences in their economic structures and their macroeconomic indicators. Considering the importance of the food industry in Europe, the biscuit production sector has been chosen to analyze at a firm level the existence of differences and a different behaviour for the 2009-2015 periods. Based on the previous literature review the following hypotheses have been proposed.

H1: Spanish and German medium firms in the food industry show structural differences.

H1a: German average firms' size surpasses Spanish average firms' size measured by number of employees.

H1b: German firms in the food industry are capable of acbieving a higher level of profitability than Spanish firms measured using return on assets (ROA) or return on equity $\mathrm{ROE})$.

H1 c: The average interest rate faced by Spanish firms is above the average value observed for German firms.

The structural difference on size can have a potential positive effect on labour productivity. Bigger firms have better financial conditions that allow for higher investment in physical capital or innovation, with a positive effect on the value added per worker.

\section{H2: There is a positive correlation between size and labour productivity.}

As has been pointed out the academic literature on firms' financial performance have considered the role played by accessing to credit and the financial cost of borrowing money in firms' investment and level of competitiveness.

\section{H3: Firms' size shows a negative correlation with interest rate.}




\section{H4: Interest rate faced by firms negatively correlates with labour productivity levels.}

H5: Due to the process of internal devaluation employees cost has growth at a lower rate for Spanish firms in the periods 2010-2012 and 2013-2015.

\section{Data and methodology}

The firm's financial information for biscuits producers in Spain and Germany comes from AMADEUS, a firms' financial information database owned by Bureau Van Dijk, with near to 21 million firms included. The selection criterion was the use of NACE code, Nomenclature of Economic Activities, selecting the code 1072; this code corresponds to biscuits producers, additional filter was to select all the available firms located in Spain and Germany. One additional criterion, considering a minimum firm size was included, only firms with more than 50 workers were selected, to exclude the bias of Spain showing a high percentage of micro firms, to consider only firms with more than 50 workers implies to select firms with bigger size and accordingly higher propensity to export and be affected by real exchange rate fluctuations. The initial sample consists of 71 firms, 35 of them are Spanish producers and 36 German firm; these are all the firms included in AMADEUS after excluding the ones without the information related to the variables used in this research. The changes in the balance sheet structure for the periods 2007-2009, 2010-2012,2013-2015 have been considered, including the percentage changes in total assets, number of employees, sales, the return on assets (ROA), the return on equity (ROE), the margin (EBIT/Sales), the productivity measured as EBIT per employee and the average interest rate paid by the firms. Table 1 summarizes the differences observed in average values for the Spanish and the German firms in the 3 periods of time considered.

\begin{tabular}{|c|c|c|c|}
\hline & $2007-2009$ & $2010-2012$ & 2013-2015 \\
\hline$\%$ average change in non-current assets Spanish firms & $4.21 \%$ & $12.59 \%$ & $7.77 \%$ \\
\hline$\%$ average change in non-current assets German firms & $14.11 \%$ & $-2.01 \%$ & $6.79 \%$ \\
\hline Average number of employees Spanish firms & 442.41 & 439.86 & 425.56 \\
\hline Average number of employees German firms & 2951.19 & 3274.69 & 2839.23 \\
\hline Average interest rate paid by Spanish firms & $5.31 \%$ & $3.94 \%$ & $3.18 \%$ \\
\hline Average interest rate paid by German firms & $13.30 \%$ & $9.46 \%$ & $9.91 \%$ \\
\hline Average ROA Spanish firms & $3.04 \%$ & $2.34 \%$ & $3.99 \%$ \\
\hline Average ROA German firms & $6.98 \%$ & $5.96 \%$ & $4.07 \%$ \\
\hline Average ROE Spanish firms & $4.86 \%$ & $3.53 \%$ & $5.51 \%$ \\
\hline Average ROE German firms & $25.87 \%$ & $19.51 \%$ & $17.74 \%$ \\
\hline Average EBIT per employee Spanish firms & $8023.08 €$ & $8863.78 €$ & $14161.74 €$ \\
\hline Average EBIT per employee German firms & $7526.98 €$ & $6666.03 €$ & $4848.09 €$ \\
\hline
\end{tabular}

Table 2. Main indicators Spanish and German firms. Source: Own elaboration based on data from SABI

Some of the results are according to what would be expected according to the academic literature and previous empirical research. German firms are bigger than Spanish firms and the difference is significant, the average size measured by number of employees is almost 6 times for a German firm compared with the Spanish ones. This data is important because the smallest firms, the ones with less than 50 employees have not been considered in the sample, consequently size is a structural difference between Spanish and German industry. The structural differences between Spanish and German firms are also reflected in the data related to profitability. Either with ROA or ROE, and whatever the period considered in the case of ROE, German firms perform better than Spanish ones. In 2010-2012, the period with lowest levels of profitability, German firms' ROE was 19.51\% compared with only $3.53 \%$ in the case of Spanish firms. The result is similar terms of ROA, the average for the German firms was 5.96\% compared with 2.34\% in the case of Spanish firms.

However, some results may be surprising. The first one relates to the average interest rate paid by firms. These values where figured out as the quotient between the interest registered in the income statement as financial expenditures and the value of long term liabilities and short term liabilities with financial institutions according to the balance sheet at the end of the year. The interest rate paid in average by the German firms has in each period being superior to the one paid by the Spanish firms, a result that is contradictory with the long term 
interest rates and the risk premium evolution being observed at a macroeconomic level. There are some factors that can contribute to explain this result, the debt in the balance sheet especially for a long term maturity can come from a past moment when interest rate were different to the current observed values, the market power of financial institutions can be different in different countries with effects in the final interest rates paid by the firms and finally some firms can finance through other options rather than bank lending; in the case of subsidiaries belonging to a firm the mother company can act as a lender applying an interest rate that is used as a way to transfer profits from the subsidiary to the mother company. Further research would be needed to understand the values obtained in this sample. The second surprising result refers to productivity; the values observed for Spanish firms are above the ones for the German firms, whatever the period considered. It is important to point out that productivity has been measured using a proxy variable, the EBIT (Earnings before interest and taxes) by employee. Although this result may be surprising, there has been some evidence on a negative correlation between productivity and size. After a minimum size it is not clear that size correlates with productivity, medium firms can show higher levels of productivity than the larger ones.

To test the different hypothesis proposed the test selected have considered the fact that according to ShapiroWilk test no one of the variables examined follow a normal distribution, consequently statistical tests used have been non-parametric. The first hypothesis was the existence of structural differences between Spanish and German firms, this leads to differences in firms' size, measured by number of employees, level of profitability, according to the ROE ratio, and the percentage of interest rate affecting the liabilities with cost. The test performed has been the Mann-Whitney, in the three hypotheses regarding the structural differences we accept the hypothesis that values showed by firms corresponding to the two countries are statistically different with a pvalue of $1 \%$.Table 3 summarizes these results.

\begin{tabular}{|l|r|r|r|}
\cline { 2 - 4 } \multicolumn{1}{c|}{} & \multicolumn{1}{c|}{$\begin{array}{c}\text { Number of } \\
\text { employees }\end{array}$} & $\begin{array}{l}\text { Interest } \\
\text { rate (\%) }\end{array}$ & Profitability ( ROE) \\
\hline Mann-Whitney Z value & -9.102 & -6.583 & -2.890 \\
\hline p-value (2 tailed) & 0.000 & 0.000 & 0.004 \\
\hline Average value Spanish firms & 397.53 & 0.0370 & 0.0741 \\
\hline Average value German firms & 2930.13 & 0.1001 & 0.1446 \\
\hline Standard deviation Spanish firms & 212.051 & 0.01877 & 0.1050 \\
\hline Standard deviation German firms & 3584.27 & 0.0859 & 0.17448 \\
\hline Number of observations for Spanish firms & 93 & 93 & 93 \\
\hline Number of observations for German firms & 42 & 42 & 42 \\
\hline
\end{tabular}

Table 3. Mann Whitney test summary. Source: Own elaboration with data from AMADEUS

Hypothesis 2 is assuming the existence of a positive correlation between size and productivity. Size has been measured using the number of employees and productivity as the ratio sales to number of employees. Based on the non normal distribution of these two variables the test selected have been the Rho Spearman correlation $(-0.480)$ and the Kendall's Tau correlation $(-0.340)$, both are significant at a $1 \%$ level. A really small size can make for a firm difficult to take advantage of economies of scale, can reduce the options to hire the most skilled workers and imply higher borrowing cost; however, once a certain size has been achieved it is not clear that higher firms are more productive, in fact, our data suggest that as size measured by number of employees increases the level of productivity drops.

Hypothesis 3 proposes a negative correlation between size and interest rate. A bigger firm has more assets that can be used as collateral when borrowing money, reducing the level of risk and consequently the interest rate applied by the lender. Bigger firms show more product and geographically market diversification leading to a lower level of risk compared with smaller firms that rely in just one product or geographical market. To test this hypothesis and due to the non-normality distribution showed by interest rate and size a non parametric correlation test has been used. Considering the subsample of Spanish firms, the Rho Spearman correlation (0.320, with a p-level of 0.004) or the Kendall's Tau correlation (0.217, with a p-level of 0.004) there is a positive correlation between size and interest rate, contrary to what hypothesis 3 was proposing. If the correlation is measured considering the available data for German firms either Rho Spearman correlation (0.021) or the 
Kendall's Tau correlation (0.019) are not significant, we cannot conclude the existence of a correlation between size and interest rate.

Hypothesis 4 tries to link interest rate and labour productivity, measured as sales generated by employee. A higher interest rate can negatively affect the level of investment in physical capital and a lower ratio Capital to labour is a cause for observing a lower labour productivity. The Rho Spearman coefficient is -0.342 and Kendall's Tau is -0.233 , both cases significant at $1 \%$ level, accepting the null hypothesis of a correlation between higher interest rate and low level of productivity.

The final hypothesis relates to the evidence in the biscuit sector of the internal process devaluation. The lack of competitiveness by Spanish firms as a consequence of higher inflation rates than Germany and other core European countries in the period previous to the financial crisis (2008-2009 and 2012-2014) has been later been compensated by a reduction in wages that helps to reduce inflation and improve competitiveness measured by the real exchange rate. We have considered data related to 2010-2012 and 2013-2015 and the increase observed in the cost per employee. To test is the differences observed are significant the Mann-Whitney $\mathrm{U}$ test has been used. For the period 2010-2012 the average increase observed in cost per employee has been $7.49 \%$ in the case of Spanish firms and just a 2.95\% for Germany firms, a result that is contradictory with the idea of an internal devaluation process. The Mann-Whitney test is not significant, so we cannot conclude that the difference is statistically significant. Results are similar considering the period 2012-2015, Spanish firms have increased in average the cost per employee in a $8.02 \%$ whereas the German firms in average have increased the employee cost in $7.28 \%$; again the difference observed is not statistically significant according to the Mann-Whitney test.

A summary of the statistical test applied, the hypothesis proposed, which ones have been accepted and the significance level can be found in Table 4 .

\begin{tabular}{|l|l|c|c|}
\hline Hypothesis & Test performed & Conclusion & Significance level \\
\hline H1a: German firms are bigger than Spanish firms & Mann-Whitney U Test & Accepted & $1 \%$ \\
\hline $\begin{array}{l}\text { H1b: German firms are more profitable than Spanish } \\
\text { firms (using ROE) }\end{array}$ & Mann-Whitney U-Test & Accepted & $1 \%$ \\
\hline $\begin{array}{l}\text { H1c: The average interest rate paid by Spanish firms is } \\
\text { above the German firms' level }\end{array}$ & Mann-Whitney U-Test & Rejected & Rejected \\
\hline $\begin{array}{l}\text { H2: There is a positive correlation between size and } \\
\text { productivity }\end{array}$ & $\begin{array}{l}\text { Rho Spearman coefficient } \\
\text { Kendall's Tau coefficient }\end{array}$ & Rejected & Accepted \\
\hline $\begin{array}{l}\text { H3: There is a negative correlation between interest rate } \\
\text { and size }\end{array}$ & $\begin{array}{l}\text { Rho Spearman coefficient } \\
\text { Kendall's Tau coefficient }\end{array}$ & Rejected \\
\hline $\begin{array}{l}\text { H4: There is a negative correlation between interest rate } \\
\text { and labour productivity }\end{array}$ & $\begin{array}{l}\text { Rho Spearman coefficient (-0.342) } \\
\text { Kendall's Tau coefficient (-0.233) }\end{array}$ & $1 \%$ \\
\hline $\begin{array}{l}\text { H5: Spanish firms' cost per employee has grown at a } \\
\text { lower rate than German firms for the periods (2010- } \\
\text { 2012) and (2013-2015) }\end{array}$ & Mann-Whitney U-Test & \\
\hline
\end{tabular}

Table 4. Summary of the hypotheses and test applied

It is worthy to mention that in the case of the hypothesis related to interest rate faced by Spanish firms and German firms in the food industry, to be more precise in the biscuits production, the Mann-Whitney test has been significant at $1 \%$ level, but the differences in values is the contrary to the one expected; average interest rate paid by Spanish firms is lower $(3.70 \%)$ to the interest rate paid by German firms (10.01\%). Similarly, the correlation between size and productivity measured in testing hypothesis 2 is significant, at a $1 \%$ level, but it is indeed a negative correlation, bigger firms are less productive than smaller ones, with a Rho Spearman correlation of -0.480 . 


\section{Discussion}

This research aimed at analyzing the structural differences showed by Spanish and German industry, the data refers to the food industry, one of the most important export industries from a European perspective, specifically biscuits producers. A second objective has been to find if a sector level there is evidence of some of the macroeconomic differences between Spain and Germany that so clearly have arise as a consequence of the financial crisis (2008-2009) and the Euro debt financial crisis (2012).

The existence of structural differences is one of the main conclusions of this empirical work. Considering only firms above 50 workers, the size showed by German firms is bigger (2930 average employees) than the one observed in the subsample of Spanish firms (397 average employees). In terms of profitability German firms outperform Spanish firms whatever is the indicator used, ROA or ROE. This result is important because higher profitability makes easier to borrow money or to use retained earnings, with possible positive effects in level of investment and labour productivity; at the end, it can improve the firms' competitiveness. An interesting result is that contrary to the expectations the average interest rates paid by German firms are above the values paid by Spanish firms. It is a fact that long interest rate have been higher in Spain than Germany as a consequence of the risk perception, however interest rate also depend on the characteristics of each national financial market and future research in this topic will be useful in understanding how macroeconomic differences transform into individual firms' conditions. These results are interesting from a policy maker point of view, many voices have asked for an industrial policy in Europe, to be aware and understand countries differences is a key element in defining an efficient policy.

At least in the case of biscuit production there is no evidence of the internal devaluation, which macroeconomic indicators so clearly have shown for Spain. One possible reason is that Spanish firms have been growing, measured either by change in non-current assets and number of employees, for 2010-2012 and 2013-2015 at higher rates than German firms. In this process of getting new employees the search for workers with the concrete skills needed is a possible explanation for the rise in the cost per employee, even in the context of a high unemployment rate. Finally, there is a correlation between interest rate and productivity. The efforts made by the European Central bank in keeping interest rate low but also in trying to reduce the differences observed between the core and the periphery of Europe make sense also in the long term perspective. Finally, in the debate between size and productivity, our results suggests that considering medium size firms, the ones with more than 50 employees, size negatively correlates with productivity; how size affects productivity is a complex topic that can have different answers depending on the special characteristics of each economic activity, and this is an interesting line of future research.

\section{Declaration of Conflicting Interests}

The author declared no potential conflicts of interest with respect to the research, authorship, and/or publication of this article.

\section{Funding}

The author received no financial support for the research, authorship, and/or publication of this article.

\section{References}

AMADEUS database- Bureau Van Dijk. Retrieved from: https://amadeus.bvdinfo.com (Last accessed date: February 2016)

Armingeon, K., \& Baccaro, L. (2012). Political economy of the sovereign debt crisis: The limits of internal devaluation. Industrial Law Journal, 41(3), 254-275. https://doi.org/10.1093/indlaw/dws029

Bartelsman, E., Haltiwanger, J., \& Scarpetta, S. (2013). Cross-country differences in productivity: The role of allocation and selection. The American Economic Review, 103(1), 305-334. https://doi.org/10.1257/aer.103.1.305 
Becker, B., \& Ivashina, V. (2014). Financial repression in the European sovereign debt crisis. Working Paper, April 2014. https://doi.org/10.2139/ssm.2429767

Bergthaler, M.W., Kang, M.K., Liu, M.Y., \& Monaghan, M.D. (2015). Tackling Small and Medium Enterprise Problem Loans in Europe. International Monetary Fund. https://doi.org/10.5089/9781498384834.006

Bernanke, B.S. (1983). Non-monetary effects of the financial crisis in the propagation of the Great Depression. The American Economic Review, 73(3), 257-276. https://doi.org/10.3386/w1054

Canton, E., Grilo, I., Monteagudo, J., \& van der Zwan, P. (2013). Perceived credit constraints in the European Union. Small Business Economics, 41(3), 701-715. https://doi.org/10.1007/s11187-012-9451-y

De Grauwe, P. (2013). Design Failures in the Eurozone: Can they be fixed?. London School of Economics, Europe in Question, Discussion Paper 57 (February 2013)

Dimelis, S., Giotopoulos, I., \& Louri, H. (2013). The Credit Crunch and Firm Growth in the Euro Area: 2005-2011. A Quantile Panel Analysis. Bank of Greece, Working Paper Series, (165).

Doğan, M. (2013). Does firm size affect the firm profitability? Evidence from Turkey. Research Journal of Finance and Accounting, 4(4), 53-59.

Ferrando, A., Blank, S., Neugebauer, K., Siedschlag, I., Iudice, M., Altomonte, C. et al. (2015). Assessing the financial and financing conditions of firms in Europe: The financial module in CompNet. European Central Bank Working Paper Series, 1836, August 2015

Holton, S., Lawless, M., \& McCann, F. (2013). SME financing conditions in Europe: Credit crunch or fundamentals?. National Institute Economic Review, 225(1), R52-R67. https://doi.org/10.1177/002795011322500107

Jõeveer, K. (2013). What do we know about the capital structure of small firms?. Small Business Economics, 41(2), 479-501. https://doi.org/10.1007/s11187-012-9440-1

Krishnan, K., Nandy, D., \& Puri, M. (2014). Does financing spur small business productivity? Evidence from a natural experiment. The Review of Financial Studies, 28(6), 1768-1809. https://doi.org/10.1093/rfs/hhu087

Marin, D. (2006). A new international division of labor in Europe: Outsourcing and offshoring to Eastern Europe. Journal of the European Economic Association, 4(2-3), 612-622. https://doi.org/10.1162/jeea.2006.4.2-3.612

Pianeselli, D., \& Zaghini, A. (2014). The cost of firms' debt financing and the global financial crisis. Finance Research Letters, 11(2), 74-83. https://doi.org/10.1016/j.frl.2013.12.002

Regan, A. (2015). The imbalance of capitalisms in the Eurozone: Can the north and south of Europe converge?. Comparative European Politics, 15(6), 969-990. https://doi.org/10.1057/cep.2015.5

Stockhammer, E., \& Sotiropoulos, D.P. (2014). Rebalancing the Euro area: the costs of internal devaluation. Review of Political Economy, 26(2), 210-233. https://doi.org/10.1080/09538259.2014.881011

Storm, S., \& Naastepad, C.W. (2015). Europe's Hunger Games: income distribution, cost competitiveness and crisis. Cambridge Journal of Economics, 39(3), 959-986. https://doi.org/10.1093/cje/beu037

The European Commission (2016). The Competitive position of the European Food and drink industry. Retrieved from: http://ec.europa.eu/DocsRoom/documents/15496/attachments/1/translations

The Eurostat (2017). Main data base. Retrieved from: http://ec.europa.eu/eurostat/web/government-financestatistics/data/main-tables

Intangible Capital, 2018 (www.intangiblecapital.org)

Article's contents are provided on an Attribution-Non Commercial 4.0 Creative commons International License. Readers are allowed to copy, distribute and communicate article's contents, provided the author's and Intangible Capital's names are included. It must not be used for commercial purposes. To see the complete license contents, please visit https://creativecommons.org/licenses/by-nc/4.0/. 